Int. Arch. Allergy 1965;27:I-IV

\title{
Contents, Vol. 27, 1965
}

International Archives

of

Allergy and Applied Immunology

Incorporating the Transactions of the Collegium Internationale Allergologicum and the

Proceedings of the International Association of Asthmology and of

National Allergy Societies

E. L. BECKER, Washington, D. C. H. BLOCH, Basel C. J. C. BRITTON, London W. E. BROCKLEHURST,

Edinburgh T. BROMAN, Göteborg L. BUSINCO, Roma A. CERLETTI, Basel A. L. DE

WECK, Bern J. DUCHAINE, Bruxelles G. ESTRADA DE LA RIVA,

Havana P. G. H. GELL, Birmingham J. GLAZER, Tel Aviv R. A. GOOD, Minneapolis, Minn.

W. GRONEMEYER,

Bad Lippspringe

CONTRIBUTING EDITORS:

A. GRUMBACH, Zurich

B. HALPERN, Paris

T. INDERBITZIN, Boston, Mass.

H. ISLIKER, Lausanne

E. A. KABAT, New York

J. LECOMTE, Liège

J. R. MARRACK, Cambridge

J. A. MORETTI, Montevideo

T. OGATA, Tokyo

A. OLIVEIRA-LIMA

Rio de Janeiro D. ORDMAN, Johannesburg 0. OUCHTERLONY, Göteborg W. PAGEL, London R. PANZANI, Marseille

C. RIMINGTON, London

M. ROCHA E SILVA, São Paulo

I. M. ROITT, London

B. ROSE, Montreal

G. RUIZ MORENO, Buenos Aires

J. RUNNSTRÖM, Stockholm

B. SCHICK, New York

E. SORKIN, Davos-Platz

A. STOLL, Basel

H. STORCK, Zurich

A. TISELIUS, Uppsala

Z. TRNKA, Geneva 
B. H. WAKSMAN, New Haven,

Conn.

G. L. WALDBOTT, Detroit, Mich. R. G. WHITE, London

R.R.A. Coombs

Cambridge

EDITORS-IN-CHIEF:

H. C. Goodman F. Halm

Geneva Freiburg/Br.

D. Harley

London

P. Kallós

$\mathrm{He}^{1 / 8 \text { ingborg }}$

W. Kaufman

Stamford, Conn.

F. Milgrom

Buffalo, N.Y.

G. B. West

London

f-' $\mathrm{fr}^{7} / 8$

1965

Vol. 27

BASEL (Schweiz) S. KARGER NEW YORK

Contents

Vol. 27

Beam, L. R.: vide Criep, L. H.

Benacerraf, B.: vide Nussenzweig, V.

Berrens, L.; Morris, J. H. and Versie, R. (Utrecht):

The Complexity of House Dust, with Special Reference to the Presence of Human Dandruff Allergen 129

Binaghi, R. A.: vide Nussenzweig, V.

Blazkovec, A. A.; Sorkin, E. and Turk, J. L. (London):

A Study of the Passive Cellular Transfer of Local Cutaneous Hypersensitivity 289

Blum, G.: vide Weck, A. L. De

Boroff, D. A. and Fleck, Ursula (Philadelphia, Pa.):

Studies of the Toxin of Clostridium Botulinum. VIII. Procedure of Rapid

Diagnosis of Botulinum Intoxication and Establishment of the Type of

Offending Toxin

Boughton, Barbara (London):

Properties of a Permeability Factor from Lymph Node Cells and its Re

lationship to Ribonucleic Acid 275

Clairmont, J. P.; Kátó, L. and Gözsy, B. (Montreal, P. Ç¿̈.): 
Investigations into the Mechanism of Pertussis Vaccine Induced Hypersensitivity. II. Effect of Insulin on Filtrating Capacity of the Capillary

Network in the Rat 46

Collins-Williams, C. and Salama, Y. (Toronto):

A Laboratory Study on the Diagnosis of Milk Allergy

Coombs, R. R. A.; Jonas, W. E.; Lachmann, P. J. and Feinstein, A.(Cambridge):

Detection of IgA Antibodies by the Red Cell Linked Antigen-Antiglobulin

Reaction: Antibodies in the Sera of Infants to Milk Proteins 321

Criep, L. H. and Beam, L. R. (Pittsburgh, Pa.):

Effect of Emulsion Injections in the Rabbit 65

Dewdney, Janet M.: vide Feinberg, J. G.

Duhig, J. T.: vide McDonald, L. W.

Eckert, Elke: vide Kellum, M. J.

Epstein, W. L.: vide Maibach, H. I.

Feinberg, J. G.; Dewdney, Janet M. and Temple, Anne (Stoke Poges):

Serum Sickness in Guinea-Pigs 175

Feinstein, A.: vide Coombs, R. R. A.

Fleck, Ursula: vide Boroff, D. A.

Furra, Daphene: vide Patnode, R. A.

Going, H. and Kaiser, P. (Frankfurt am Main):

Experimentelle Untersuchungen zur Immunthrombozytolyse

Good, R. A.: vide Kellum, M. J.

Gözsy, B.: vide Clairmont, J. P.

Heather, C J.: vide Turk, J. L.

Hercules, H.: vide Lima, A. O.

Hermann, G. and Miescher, P. A. (New York):

Differentiation of Leukocytic Fibrinolytic Enzymes from Plasmin by the

Use of Plasmatic Proteolytic Inhibitors 346

Hildebrand, G. J.: vide Ng, J.

Jonas, W. E.: vide Coombs, R. R. A.

Jonsson, J. (Stockholm):

Application of Mixed Haemadsorption - a Mixed Antiglobulin Reaction

to Soluble Antigens Fixed on Glass Slides 157

Jung, E. G. and Schwarz, K. (Zurich):

Photoallergy to Jadit' with Photo Cross-Reactions to Derivatives of Sul-

fanilamide 313

Kaiser, P.: vide Going, H.

Kátó, L.: vide Clairmont, J. P.

Kellum, M. J.; Sutherland, D. E. R.; Eckert, Elke; Peterson, R. D. A. and Good, R. A.

(Minneapolis, Minn.):

Wasting Disease, Coombs-Positivity and Amyloidosis in Rabbits Subjected

to Central Lymphoid Tissue Extirpation and Irradiation

6

Lachmann, P. J.: vide Coombs, R. R. A.

Lima, A. O.; Seabra, O.; Pradez, G. F. and Hercules, H. (Rio de Janeiro):

Effect of Serum Complement on Systemic Heterophil Anaphylaxis of Mice 304

Lupulescu, A.; Pop, A.; Potorac, E.; Oprisan, R. and Merculiev, E. (Bucharest): 
The Effect of Thymectomy on the Course of Isoimmune Thyroiditis in Guinea-Pigs 257

Maibach, H. I. and Epstein, W. L. (San Francisco, Calif.):

Immunologic Responses of Healthy Volunteers Receiving Azathioprine

(Imuran) 102

Manclark, C. R. and Pickett, M. J. (Los Angeles, Calif.):

A Proposed Role of in vivo Uterine Anaphylaxis in the Etiology of Abortion

and Sterility 54

McDonald, L. W. † and Duhig, J. T. (Berkeley, Calif.):

Optimum Conditions for Using Agar Gel Microtechniques 27

Merculiev, E.: vide Lupulescu, A.

Miescher, P. A.: vide Hermann, G.

Milgrom, F. and Schultz, R. T. (Buffalo):

Serodiagnosis of Rheumatoid Arthritis Based on Inhibition of Anti-

complementariness of Denatured Fraction II 338

Morris, J. H.: vide Berrens, L.

Ng, J.; Seys, Y. M. and Hildebrand, G. J. (Berkeley, Calif.):

Role of Hyperreactivity of Bronchial and Pulmonary Vascular Muscle to

Acetylcholine and Histamine in Anaphylactic Shock in Rabbits and

Guinea-Pigs 35

Nussenzweig, V. and Benacerraf, B. (New York):

Electrophoretic Patterns at Acid and Alkaline $\mathrm{pH}$ of Reduced Guinea-Pig

7S Gamma Globulin and Anti-Hapten Antibodies of Different Specificities 193

Nussenzweig, V. and Binaghi, R. A. (New York):

Heterogeneity of Rat Immunoglobulins 355

Oprisan, R.: vide Lupulescu, A.

Patnode, R. A. and Furra, Daphene (Oklahoma):

Increased in vitro Tuberculin and Endotoxin Leukocytolysis Following Skin

Tests with Homologous and Heterologous Substances 269

Peterson, R. D. A.: vide Kellum, M. J.

Pickett, M. J.: vide Manclark, C. R.

Pop, A.: vide Lupulescu, A.

Potorac, E.: vide Lupulescu, A.

Pradez, G. F.: vide Lima, A. O.

Radermecker, M. (Liège):

Comparaison de la sensibilité cutanée à Thistamine et à la bradykinine de

Thomme allergique et non allergique 213

Salama, Y.: vide Collins-Williams, C.

Schultz, R. T.: vide Milgrom, F.

Schwarz, K.: vide Jung, E. G.

Seabra, O.: vide Lima, A. O.

Segre, D. and Sharp, J. B. (Urbana, Ill.):

Quantitation of Delayed Hypersensitivity in Guinea-Pigs by a Local

Passive Transfer Reaction $\quad 82$

Seys, Y. M.: vide Ng, J.

Sharp, J. B.: vide Segre, D. 
Sorkin, E.: vide Blazkovec, A. A.

Sutherland, D. E. R.: vide Kellum, M. J.

Temple, Anne : vide Feinberg, J. G.

Turk, J. L. and Heather, C. J. (London):

A Histological Study of Lymph Nodes During the Development of Delayed

Hypersensitivity to Soluble Antigens 199

Turk, J. L.: vide Blazkovec, A. A.

Versie, R.: vide Berrens, L.

Weck, A. L. de and Blum, G. (Bern):

Recent Clinical and Immunological Aspects of Penicillin Allergy ... 221

Book Reviews 63, 318

News Items 320

Proceedings British Allergy Society; Meeting of the 9th January 196562

International Symposium on Immunological Tolerance; Locarno May

$1-3,1965 \quad 361$

All rights, including that of translation into foreign languages, reserved.

Photomechanic reproduction (photocopy, microcopy) of this book or part of it without special permission of the publishers is prohibited.

(C)

Copyright 1965 by S. Karger AG, Basel

Printed in Switzerland by Buchdruckerei Aargauer Tagblatt AG, АaГau

Cliches: Steiner \& Co. AG, Basel 